\title{
Curie Intensity Score 1
}

National Cancer Institute

\section{Source}

National Cancer Institute. Curie Intensity Score 1. NCI Thesaurus. Code C133474.

Doubtful uptake within a segment. 